\title{
Epic romance on Western and Eastern Fronts
}

\section{Introduction: the romance of volunteer work}

Most volunteer nurses of the First World War were female, young, and - within the limits of their time - well educated. They were more likely than trained nurses to publish memoirs of the war. Somewhat paradoxically, they were also more likely to write about the intricacies of nursing practice. While the writings of trained nurses focused on the courage and endurance of patients, those of volunteers emphasised the drama of nursing itself. Chapter 8 explored the ways in which some British VADs observed the work of their professional colleagues and reflected on their own struggle to acquire competence without becoming emotionally detached from their patients' sufferings. But, for many volunteer nurses, the 'romance' of nursing went beyond the execution of nursing skills.

Cultural historian Paul Fussell has suggested that the 'romantic' trope was a familiar one to the young men of the early twentieth century, and was the result of their exposure to romances such as William Morris's The Well at the World's End and John Bunyan's Pilgrim's Progress. ${ }^{1}$ The romantic, narrative trope involved the testing of a (male) hero, through the 'ordeal' of his experience. If he could withstand this test, he would be transformed through 'apotheosis' - a process that mirrored religious ideas of transcendence. The hero was, therefore, not just courageous, but also saintly: morally and spiritually pure. For the young men of the war generation, combat was their ordeal; surviving it with 'honour' would result in self-transformation. 
Such 'myths' were exploded, after the war, by writers such as Siegfried Sassoon, Edmund Blunden, Henri Barbusse, and Erich Maria Remarque, who exposed the contrast between the romance trope and the ugly realities of modern, industrial warfare.

Volunteer nurses were mostly drawn from the middle or upper classes of their societies; they, too, were likely to write in ways that drew upon the 'high culture' of their time. Young, female nurses were exposed to many of the same romantic ideals that held such power over their brothers. But, for them, the romance trope was a complex one. Women in traditional, western romance had been portrayed as either passive victims, to be rescued from danger by male heroes, or as villainesses against whom the hero must battle. Rarely had they been actors at the centre of their own adventures. Now a new generation of young women was beginning to develop a new perspective: volunteer nurses found ways in which to view themselves as heroines. A new genre of female adventure-writing, with popular authors such as Bessie Marchant at its vanguard, ${ }^{2}$ was already influencing girls to believe that they could situate themselves at the centre of their own stories: that they could even, through their own courage and adaptability, be the makers of their own futures. A new feminine myth was emerging, and volunteer nurses were determined to enact it. They were not to know that the realities of industrial warfare were soon to expose it as a hollow fiction.

\section{Ordeals on the Western Front}

Not all British volunteer nurses were 'VADs'. Henrietta Tayler, a keen volunteer who offered her services to the Anglo-French Red Cross, appears to have embarked on - but been unable to complete - a formal course of training. She clearly considered herself to be as skilled and knowledgeable as most fully trained nurses, and was chagrined at her lack of a formal qualification, commenting that she had 'had to bear the stigma of the semi-trained; a stigma that I have tried, as we all do, to rub off with extra hard work. ${ }^{3}$

In 1916, after eighteen months' experience of running a VAD hospital in Scotland, Tayler was posted by the 'Anglo-French section of the British Red Cross' to L'Hôpital de l'Océan, in La Panne, Belgium. She was probably there for some months before Violetta Thurstan's 
arrival as matron. She considered service at L'Hôpital de l'Océan a privilege and wrote of the prestige of being sent to 'Dr Depages famous ambulance ... a splendid organization. ${ }^{4}$ She commented on the level of innovation and specialisation within the institution, which had units devoted to patients with abdominal, chest, head, and eye wounds, as well as wards for fracture cases, for patients with 'nerve lesions', and 'one especially devoted to experimental treatment of complicated cases with all the newest therapeutic discoveries. ${ }^{5}$ She pointed out that almost all wounds were treated using the most up-todate method - irrigation using the Carrel Dakin technique - declaring that L'Hôpital de l'Océan shared with the Rockefeller Institute at Compiègne 'the distinction of being the best exponents of the system. ${ }^{6}$ Tayler seems to have taken great delight in being at the vanguard of clinical practice. If she had a 'romance quest' it was, clearly, to prove herself a good nurse and, in pursing her goal, she underwent ordeals of both a clinical and a personal nature. The work was onerous, and she found herself burdened by responsibility:

I shall never forget one lurid night I passed with three [French North African patients] and ten other patients, the Sister in charge being engaged elsewhere; one brown man had to have injections of huile camphrée hourly, another morphia whenever his pain became unbearable, and the third was coughing up his lungs all night, and died before morning. The other two lived to be moved to another ward, but not much longer.?

She comments, in the dry and somewhat patronising language of the British imperialist, on how 'one Frenchman, belonging to the famous Algerian regiment of Joyeux, who gave us a great deal of trouble, desired me to write to his father that he had died the death of a hero and, when I pointed out "Nous ne sommes pas encore à ce point-là" was quite hurt. Him, I did manage to see again, being very noisy in another ward.' Another patient, who 'was proud of his command of the English language, kept crying pathetically for hours: "Seestair, seestair, elevate me - I cannot respire."' Tayler explained to him that the nature of his wound meant that he must lie flat, but it took some time to convince him of this. ${ }^{9}$

Overwork and proximity to infection meant that Tayler contracted pneumonia, and was sent to the 'sick house', where she listened to the sounds of military funerals outside her window, wondering if she, too, would soon die, and writing, in somewhat dramatic tones, of how 
she had made 'the one person I really trusted promise to tell me when that moment seemed imminent, while holding fast to her hand, to combat the ghastly sensation of falling, falling, falling through the floor of the world!! ${ }^{10}$

Volunteer nurses did not have to endure near-death experiences to find themselves on perilous journeys or enduring ordeals that would change their perceptions of life. Olive Dent, in her prosaically titled $A$ VAD in France, offers the following account of night duty in a base hospital:

Naturally, we have had nights never-to-be-forgotten ... all the devlish [sic] horror and wracking torture of living again the eternal age with its waiting, waiting, waiting in No Man's Land, nights when a dying man on whom morphia has had no effect has persistently cackled ragtime while another, one of the very, very few who have realised they are in the Valley of the Shadow, - reiterated again and again 'I'm dying, I'm dying, I'm dying' ... tense moments when we have fought for a life with strychnine, morphia, salines, nutrients, and hot-water bottles, crowded moments when, our lamps throwing Rembrandt shadows and gleams around the dark tent with its rows of huddled, maimed forms, there has been plugged and stemmed a haemorrhage from a place where the surgeon could not ligature ... One's eyes smart and feel filled with salt as a man with life ebbing - oh! so painfully quickly, - grasps one's hand and says 'Sister, God bless you.' The full meaning of the remark arrests one, its sanctity, its solemnity, the benedictory significance of the words spoken under such circumstances engulf one. ${ }^{11}$

Dent's extraordinary writing contains all the motifs of the romance quest: the strange eeriness of the lamp-lit base hospital ward with its 'Rembrandt shadows'; the 'devlish horror and wracking torture'; the reverential moments when men pass through 'the Valley of the Shadow'; the apotheosis - the moment of spiritual transformation, when the dying patient says 'God bless you'. The episodes described by Dent suggest that night duty was filled with moments of spiritual truth. For most nurses, its reality probably had much to do with cups of cocoa, the carrying of bedpans and vomit bowls, and the regular medicine-round. But Dent may have been speaking for her generation when she infused such meaning into her work. And the motif she used was one that her generation would have recognised.

An anonymous American writer, who entitled her memoir of the war Mademoiselle Miss, wrote of her 'unique and inexpressible life' in a French Red Cross hospital. ${ }^{12}$ At the outbreak of war she served 
as 'helper in a small French hospital on the Riviera' and then in an English hospital at Mentone. ${ }^{13}$ Eventually, however, she decided to take the examination for a 'nurse's diploma in the French Red Cross' and joined a French military hospital on the Marne. ${ }^{14}$ On 20 September 1915, she described her first experience of enemy shelling: 'It is a sensation so vast and lonely and crowded and cosmic all at once that one seems born into a new phase of existence where the old ways of feeling do not answer any longer. ${ }^{15}$ Part of her purpose in writing seems to be to present the French military hospital as the strange, spellbinding place of legend and romance: 'It is all like a weird dream, laughter (for they laugh well, the soldiers) and blood and death and funny episodes, and sublime also, all under the autumn stars. ${ }^{36}$

Most volunteer nurses had had minimal prior experience of ward work; their entry into the military hospital was preceded by only a few months' nursing work in a civilian or auxiliary hospital. It is probably because of their naivety and inexperience that their writings are, typically, filled with a sense of wonder at being in the presence of suffering patients and staff who are taking life-or-death decisions. The disjointed, strange, and contradictory qualities of memoirs such as $A$ $V A D$ in France and Mademoiselle Miss lure the reader into a sense of unreality - a feeling that one has entered a dream-world: a spiritual realm. Their authors juxtapose fantasy with horror.

\section{'Wide open world': the adventures of Florence Farmborough}

Stored in the Imperial War Museum, London, are seventeen reels of tape recording a conversation between memoirist Florence Farmborough and interviewer Margaret Brooks. In the first reel, Farmborough, in the high, cultured voice of a gentlewoman, tells of her childhood. Her narration is slow and deliberate, filled with certainty and self-belief, never faltering, offering what sounds almost like a recitation. She is conscious of the importance of her story, and therefore of her life. Her interview is not just a record; it is a piece of self-composure. ${ }^{17}$ Florence Farmborough retold the story of her life and nursing work several times, through memoirs and interviews, each time capturing a sense that her life in Russia was a romantic mission - a journey into the unknown and a quest for discovery. ${ }^{18}$ 
Florence Farmborough's original diary was almost certainly written contemporaneously with the events it describes. Containing extended passages relating to specific events, it offers a vivid insight into her wartime nursing experiences; but it is disjointed, lengthy, and difficult to navigate. Her memoir offers a more reflective account, in which time has been foreshortened, apparent irrelevances are omitted, and events are ordered. Although it still often relates scenes of chaos and confusion, the text itself is carefully arranged and adjusted to permit the reader to follow Farmborough's spiritual journey as a neophyte nurse, as well as her geographical one first as a member of a Russian flying column and then as a British subject escaping from revolutionary Russia. The oral history interviews Farmborough gave to Margaret Brooks and Peter Liddle were conducted soon after she had published Nurse at the Russian Front, and both are strongly influenced by the memoir. It is as if, by this time, her life has ceased to be a succession of events and has become a carefully constructed recitation based on those events.

Florence Farmborough was born in 1887 at Steeple Claydon, Buckinghamshire, close to the Claydon estate of Florence Nightingale's brother-in-law, Sir Harry Verney. She was, in fact, named after Nightingale, ${ }^{19}$ and this may have influenced her later decision to nurse the Russian wounded - although her narrative depicts her being swept into war service by the enthusiastic patriotism of her Moscow circle.

One of Farmborough's primary motivators was the desire to travel: 'I had decided', she says in her 1975 interview, 'long, long before anyone else knew it that I was going to be a traveller. ${ }^{20}$ This desire became 'a tremendous objective', which was fulfilled when, at the age of nineteen (but claiming to be twenty-one), she went to East Galicia to be a governess. She speaks of a 'tremendous feeling of wonderment - a tremendous thrill' upon first seeing the Carpathian Alps, followed by a desire 'to climb and see where [they] ended and what was beyond those enormous peaks. ${ }^{21}$ Her quest was to take a form that not even she could have imagined.

Farmborough first went to Russia in 1908. Her post was in Kiev, a city that she found exhilarating and moving: both 'splendid' and deeply spiritual. ${ }^{22}$ She then travelled to Moscow, where she took a position as governess to the two daughters of renowned heart specialist Dr Pavel Sergeyevitch. Her Russian employers were kind and 
treated her as a part of their family; and her experience of Moscow was remarkably similar to that of Violetta Thurstan. Like Thurstan, she was fascinated by Russia's bells: 'It was said in those days that there were 40 times 40 churches and holy shrines in Moscow, and so you can imagine [on holy days] 40 times 40 bells rang out from all these great and small beautiful architectural edifices. And the whole city was resounding with the music of bells.' ${ }^{23}$ Hearing Farmborough's voice, as she recounts her early experiences of Kiev and Moscow, a listener cannot help but be struck by her deep sense of nostalgia. With the hindsight of sixty years, and speaking in a world still fractured by the cold war, in which Eastern Europe and Russia were concealed behind an 'Iron Curtain', she was profoundly aware of 'her' Russia as a lost place that could never be recaptured: a place of myth, legend, and enchantment, where there were cities with ' 40 times 40 bells'.

In Moscow, Farmborough came to identify herself with her Russian family. She decided to play her part in Russia's war by enrolling, along with her two young charges, as a volunteer nurse. ${ }^{24}$ In early-twentieth-century Russia, there were few nurse training schools; most civilian nursing was undertaken by Sisters of Mercy. Following a six-month Red Cross training, and a series of examinations, Farmborough was considered a fully qualified surgical nurse. Her experience casts light upon the findings of Violetta Thurstan, who was struck, during her time in Poland, both by the technical precision of the Russian 'nurses', and by their lack of wider nursing knowledge and skill. ${ }^{25}$

Farmborough enrolled in the 10th Surgical Unit of the all-Russian Zemski Soyuz, and was delighted to find herself posted to a letuchka, or 'flying column' - a rapidly moving mobile field hospital - based on the Eastern Front in the Carpathian Mountains. ${ }^{26}$ She narrated her experiences not only in her remarkable memoir, Nurse at the Russian Front, but also in her Russian Album, her remarkable pictorial record of a vanished world. Her photographs capture a series of tantalising images of pre-war, wartime, and revolutionary Russia. From them stare the people of a lost generation, and alongside stands a clear and precise narration of events, interrupted with the occasional deliberately loaded comment. In the opening chapter, Farmborough announces: 'I went to Russia in 1908. I was twenty-one, with an urge to travel that had been with me since my earliest years. Reflecting now 
upon my travels, I have said that I loved Russia the most because she taught me the meaning of the word "suffering"'. ${ }^{27}$

In Nurse at the Russian Front, Farmborough relates her story in romantic terms: it consists of an epic journey through a vast, enchanted yet dangerous landscape in which both courage and resolve are tested. Transformation, or 'apotheosis', is reached on a final long, slow journey through Siberia with the realisation that even the cataclysm of the Russian Revolution cannot touch Russia's 'wide, changeless spaces', which 'bring only comfort and peace. ${ }^{28}$ Much of the book reads as a traveller's tale,$^{29}$ and its mood is loaded with the excitement of adventure, as its heroine faces danger and holds her nerve. On one occasion, Farmborough finds herself in acute danger, as a 'folvark' (an inn) in which she and her colleagues are spending a night is shelled. Her description is infused with dramatic tension: 'The noise was deafening; the house rocked as in an earthquake; a crash of timber splitting, falling; a cascade of broken glass spilling from a height. ${ }^{30}$

Although she describes with care the episodes in which she finds herself in physical danger, it is the intensity of her moral, nursing dilemmas that Farmborough seems most keen to transmit to her readers. In one episode, she describes how she is forced to choose between rejoining her departing column, or remaining with a dying man who has begged her not to leave him. ${ }^{31}$ In another, she describes how she resolves the ethical dilemma of caring for a soldier with self-inflicted wounds, by deciding to cover the 'dark tell-tale stain of a wound received at close quarters' with iodine and a bandage and despatching the man to base before his 'cowardice' can be discovered and punishment meted out. ${ }^{32}$ One of the most moving passages in her 'diary', however, is the one in which she describes 'hastening a soldier's death through my disobedience. ${ }^{33}$ Having been told not to give any food or fluid to a 'stomach case' who has had surgery the previous night, she is confronted by a man who is clearly desperate for water. She is certain that he is dying:

His cries for water were insistent; he was beseeching, imploring; his thirst must have been agonising. Near one of the other men, a mug of water was standing. He had seen it and, raising an arm, pointed towards it. His eyes challenged mine; they were dying eyes, but fiercely alight with the greatness of his thirst. I reasoned with myself: if I give no water, he will die tormented 
by his great thirst; if I give him water, he will die, but his torment will be lessened. In my weakness and compassion, I reached for the mug; his burning eyes were watching me; they held suspense and gratitude. I put the mug to his lips, but he seized my arm and tilted the mug upwards. The water splashed into his open mouth, sprayed his face and pillow, but he was swallowing it in noisy gulps. When I could free my arm from his grasp, the mug was empty. I was deeply distressed and knew that I was trembling. I wiped his face dry and he opened his eyes and looked at me; in them, I saw a great thankfulness, an immense relief. But, before I could replace the mug, a strange gurgling sound came from him, and out of his mouth, there poured a stream of thick, greenish fluid; it spread over the stretcher-bed and flowed on to the floor. His eyes were closed and ... he had stopped breathing. ${ }^{34}$

Farmborough's writing skilfully draws out the reader's emotions: horror at the man's death; relief that the nurse has granted his wish; fear that she has failed to obey an order; suspense at what the final outcome will be. Farmborough comes to understand the impossibility of achieving perfect solutions to the ethical dilemmas of nursing practice, and the peace of knowing that she has prioritised the easing of suffering over obedience to orders. She concludes that 'all my life I should have the grievous memory of hastening a soldier's death through my disobedience; but, at the same time, there would be another less grievous memory: that of a pair of dying eyes looking at me with infinite gratitude. ${ }^{35}$ In volunteer nurses' writings, episodes such as these represent the trials or tests that must be passed. If the male test is 'ordeal by combat' with its life-or-death outcome, then the female test is 'ordeal by suffering' - her own and that of others.

\section{Broken spell: war and revolution in the writings of Mary Britnieva}

Little is known about the experiences of Russian nurses - particularly those of the Sisters of Mercy, who relinquished their civilian practice for war service. Yet the memoirs of war-trained volunteer nurses can fill some of the gaps in the historical record, as well as offering insight into the experiences of middle- and upper-class women, who chose to serve as nurses. ${ }^{36}$ Mary Britnieva was a member of the Anglo-Russian gentry at the outbreak of war in 1914. Her memoir of war and revolution, covering the period from 1914 to 1930 , is a blend of one highly 


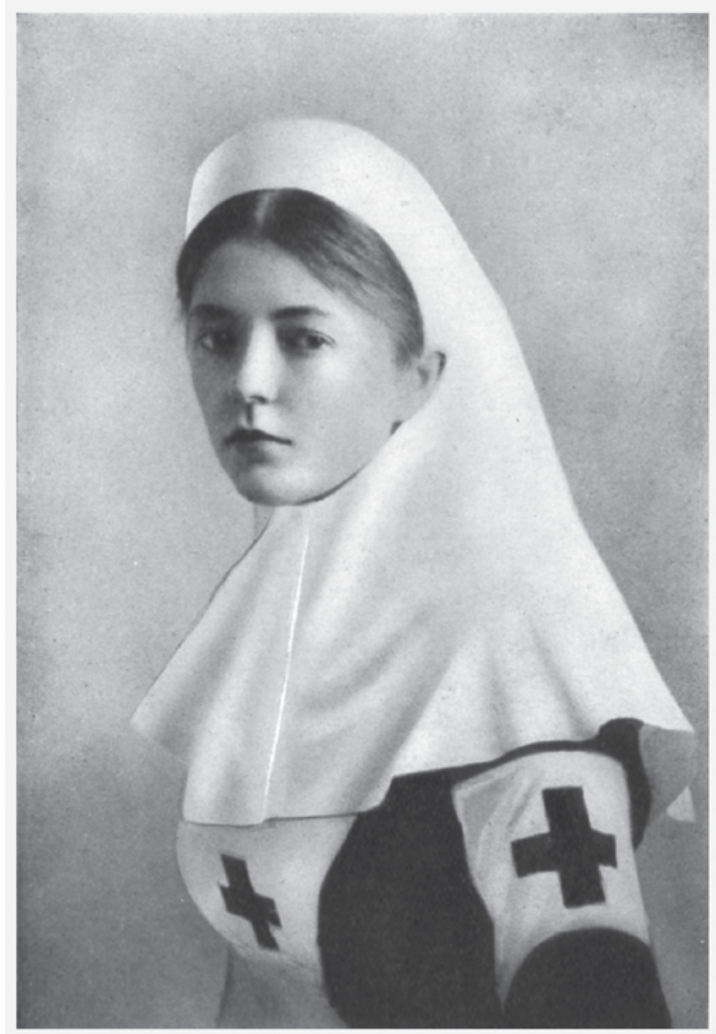

Figure 10 Portrait of Mary Britnieva

personal and tragic life-story with a sweeping, epic retelling of a turbulent period in Russian history. ${ }^{37}$ Her narrative begins with the departure for the Eastern Front of the flying column to which she is attached. It ends with her narrow escape from the Soviet Union following an unsuccessful attempt to rescue her doctor-husband from the Stalinist purge of the 'intelligentsia'. The book's tone resonates with a sincere attachment to everything she considers to represent the 'old Russia' - a dying nation, which is being ruthlessly purged and rapidly replaced by a soulless and heartless bureaucracy. She avidly records any experience that suggests that the spiritual life of Russia and its people still lives and cannot be 
extinguished, and her book is clearly a deliberate attempt to keep alive the memory of everything that was ruthlessly wiped out by war and revolution.

Britnieva's memoir is pervaded by a feeling of nostalgia. It was written in the early 1930s when her feeling of loss and grief must still have been raw. Episodes in which she was happy - many of which took place at the height of war when the Russian army was retreating with huge losses - are recollected with warmth and pleasure. Ultimately, the book is a reflection on the destruction of Russian society and culture. Britnieva conveys a sense that the Russian people were, in the second and third decades of the twentieth century, 'sleepwalking' to their own destruction, unable to see what was happening to them until it was too late. In fact, the phrase 'too late' becomes Britnieva's meditation. She puts the words into the mouth of Russian intellectual Anatoli Feodorovitch: 'It seems to me that the most terrible, the most tragic thing that can befall one in life is to be too late. "Pozdno" (too late), what a cruel, what a relentless word! In its finality it is far more terrible than Death itself, and, being irrevocable, far, far worse than Never! ${ }^{38}$

Mary Britnieva had enjoyed a privileged childhood as part of a wealthy Anglo-Russian family living in Petrograd. Towards the end of her book, she compares her former self with the children of the newly emerged Bolshevik elite, recognising that, in her youth, she had been spoiled, 'unconscious and blissfully ignorant' of the lives and conditions of the impoverished Russian proletariat. ${ }^{39} \mathrm{~A}$ powerful sense of patriotism pervades her thinking and she describes how her first instinct at the outbreak of war was to train as a 'war nurse. ${ }^{40} \mathrm{Her}$ training was probably very similar to that of Florence Farmborough. She was delighted to learn that she was to be appointed to a flying column, which operated under the patronage of the Russian Council of State. At this early point in the book, the reader is introduced to the man who is to become Britnieva's husband, although we never learn his name. ${ }^{41} \mathrm{He}$ is 'the head doctor', 'a well-known surgeon and a brilliant organizer. ${ }^{42}$

For Britnieva, as for Florence Farmborough, the greatest trials she describes in this early part of her book are those associated with the care of the dangerously ill. Yet, her descriptions of her work resonate with an almost childish sense of excitement and adventure: the care 
of the wounded is a challenging game; winning brings the thrill of achievement:

How excited I was when my first patient was brought! He was a German prisoner called Koppe and had peritonitis, being very seriously wounded in the stomach. Our head doctor had operated on him, extracting several bullets from his liver, which was (he found) practically in pieces. Koppe was hardly expected to live, his condition being almost hopeless, but thanks to his wonderful patience and amazing stoicism, he pulled through. For nine days after his operation he was not allowed to drink - only having his tongue moistened now and again with a drop of water. ${ }^{43}$

Although she gives credit to the patient for his 'wonderful patience and amazing stoicism, Britnieva seems also to be experiencing an unspoken sense of achievement in her own work. The outcome for Koppe is very different from the terrible death experienced by Farmborough's patient in her Nurse at the Russian Front. Britnieva's lack of enmity towards her German patient is also striking, particularly in view of her intense patriotism. Her writing conveys a sense that wartime nursing is a humanitarian endeavour, not very different from Red Cross work in times of natural disaster such as earthquake or epidemic.

Britnieva's war can be read through her memoir as a great adventure and an epic journey. Her descriptions of long and romantic treks through beautiful Eastern European landscapes are typical of Eastern Front nursing memoirs. ${ }^{44}$ In December 1914, during the German advance into Poland, the flying column to which Britnieva was attached spent several weeks occupying an old and beautiful palace named Teresino. Here, the unit cared for some of the most horrifically wounded patients, including the victims of gas attacks. Yet, Britnieva remembers this time as one of the happiest of her life. Her description of arrival in Teresino is redolent of an episode in a fairy tale:

It was a beautifully clear moonlit night and the frost had formed a soft crust on the snow's surface which crunched pleasantly under our feet as we crossed the field and entered the wood ... our excitement reaching its culminating point at the magic sight that met our eyes when we reached a clearing in the park. A real fairy palace with turrets and galleries, gleaming white and dazzling in the moonlight, stood before us ... We stood spellbound. ${ }^{45}$

The words 'spellbound', 'magic', and 'fairy palace' infuse Britnieva's account with a feeling of enchantment - almost as if she wants to 
convey a sense that she was living in a dream. If so, she soon brings the reader back to reality, as she describes how 'a steady stream of ambulances' arrived at the hospital, and the nurses found themselves 'up to their necks' in work. Patients arrived with 'shockingly' infected wounds and many died, in spite of the hospital's reputation for having the highest survival rate on that part of the Eastern Front. ${ }^{46}$

Following her return home on leave, Britnieva takes another journey, this time to her mother's estate in Chistopol, in the Government of Kazan. Her fiancé meets her there, and once again, she conveys a sense that she is living in a fantasy world: 'A feeling of peace reigned everywhere. The War seemed something unreal, remote, untrue. It seemed unbelievable that somewhere men were fighting and killing one another, when the world was so unspeakably lovely. ${ }^{37}$ Britnieva's determined exaggeration - her concern to convey how 'unspeakably lovely' her world was - undoubtedly reflects her sense of loss, as she writes her book in exile, in Britain, sensing that she will never return to her homeland. She writes of 'how infinitely beautiful' her country was, and of 'how little we guessed the dark terrible tragedy that was to befall her in a year's time.48 As the world of her childhood slipped away, Britnieva's real ordeal was beginning. And yet, her narrative itself does not become dark. It may be that her determined focus on all that remained beautiful in her world was part of a deliberate project to bring her sense of the spirit of Russia into the minds of a western readership. No less than those of British writers such as Millicent Sutherland or Sarah Macnaughtan, Britnieva's project was a patriotic one. For her western audience, Russia was another world - entirely out of reach - and Britnieva plays upon this notion of a 'lost world' by infusing her writing with a dreamlike quality. But this dream is both fantastic and utopian: and the Russia she creates owes as much to her own powerful and creative writing as to reality.

Britnieva married at the beginning of 1918, 'almost a year after the abdication of the Tsar and several months after the Bolsheviks had seized power. ${ }^{2} 9$ She conveys a sense that, even as her personal life is taking a new and satisfying course, the life of her nation is gradually being strangled by the Bolshevik Revolution, the decline into civil war, and the New Economic Policy. ${ }^{50}$ At the end of the 1920s, Stalin's 'revolution from above', incorporating the collectivisation of agriculture, the industrial drive of the first Five Year Plan, and the 'Cultural Revolution' 
directed against the old intelligentsia, swept away the last remnants of Britnieva's 'old Russia. It is only with hindsight that one can view these events as episodes in a tragic - albeit temporary - process of social, economic, and cultural devastation. Sheila Fitzpatrick has commented that the twenty-first century has chosen to view the Russian Revolution as 'a wrong turning that took Russia off course for seventy-four years. ${ }^{51}$ For those living through these events, there was always the hope that stability would return. For Britnieva, 'these new-fangled persons who called themselves Bolsheviks' had created 'complete chaos in every single branch of life which was the only visible consequence of their advent to power. ${ }^{52}$ As members of the so-called 'intelligentsia' - an inchoate group of highly educated and skilled individuals - Britnieva's family were under threat. Although the Russian intelligentsia held 'passive liberal attitudes rather than active revolutionary commitment to political change, ${ }^{53}$ they were identified as the 'class enemies' of the new state, and as such were subjected to the 'totalitarian terror' meted out first by the radicalised Bolsheviks and then by Stalin's autocracy. Britnieva traces the tragic destruction of this group. ${ }^{54}$ Although Britnieva herself, with a claim to British citizenship, was able to escape from Bolshevik Russia with her children, her husband remained behind. Britnieva made several visits, but on the final one she was unable to trace her husband, learning only weeks after his death that he had been executed in prison. Returning home and looking through his possessions, she found a letter stamped 'Chistopol - May 1916'. Her words express the nostalgia that infuses her entire book: 'The glittering Kama in the distance ... How long ago! How far away.... 55

\section{Conclusion: 'ordeal' and 'apotheosis'}

For many of those who nursed the wounded of the First World War, their experiences were more extraordinary than anything they could have imagined. In writing of those experiences, they drew upon cultural conceptions of 'the extraordinary', 'the magical', and 'the amazing, to fit their own narratives into a romantic trope that was only just beginning to be recognised as dangerous. Their perspectives would, by the end of the twentieth century, be regarded as archaic and naive. Their stories contain 'ordeals' in which they battle death, and often 
resolve into 'apotheoses' in which 'suffering' somehow becomes the highest spiritual truth. The romantic narrative trope was especially powerful in the memoirs of volunteer nurses, and was particularly likely to be applied to experience on the Eastern Front. Individuals such as Florence Farmborough and Mary Britnieva produced stories of their own lives, which take notions of 'self-composure' to the highest level, presenting the nurse writer as the heroine of her own adventure. Yet, these are not works of deliberate propaganda or self-promotion; their writers seem to want only to bear witness to the extraordinary times through which they lived.

One of the most frequently cited reasons for publishing a war diary was the compulsion to bear witness to the horrors of war. Authors wrote of their desire to tell the truth. Yet the truth differed depending upon background, perspective, and experience; it was coloured by cultural and ideological influences. For VADs, their backgrounds as genteel middle- and upper-class ladies of the British Empire brought a strong element of patriotism to their writings, even as they began to realise that the war was not the simple crusade against a marauding Teutonic horde they had believed it to be. It also inclined them to express a remarkable level of confidence in their own natural abilities as nurturers of the wounded..$^{56} \mathrm{~A}$ project that they embraced with particular eagerness was the presentation of nursing itself as an ordeal, through which only the strongest could pass unscathed. The 'truth' that most seemed anxious to convey was that nursing work was a transformative process, which, if approached with a genuine desire to alleviate suffering, could have a profoundly positive effect not only on the patient, but on the nurse herself.

\section{Notes}

1 Paul Fussell, The Great War and Modern Memory (Oxford: Oxford University Press, 2000 [1975]): 135-44. See also: Benedict Anderson, Imagined Communities: Reflections on the Origin and Spread of Nationalism (London: Verso, 1991).

2 Michelle Smith, 'Adventurous Girls of the British Empire: The Pre-War Novels of Bessie Marchant', The Lion and the Unicorn, 33.1 (2009): 1-25.

3 Henrietta Tayler, A Scottish Nurse at War: Being a Record of What One Semi-Trained Nurse Has Been Privileged to See and Do during Four and a Half Years of War (London: John Lane, 1920): 15. 
4 Tayler, A Scottish Nurse at War: 29-30. On L'Hôpital de l'Océan, see Christine E. Hallett, Veiled Warriors: Allied Nurses of the First World War (Oxford: Oxford University Press, 2014): 40-3.

5 Tayler, A Scottish Nurse at War: 30.

6 Tayler, A Scottish Nurse at War: 30.

7 Tayler, A Scottish Nurse at War: 39.

8 Tayler, A Scottish Nurse at War: 39.

9 Tayler, A Scottish Nurse at War: 40.

10 Tayler, A Scottish Nurse at War: 42.

11 Olive Dent, A VAD in France (London: Grant Richards, 1917): 282-7.

12 Anon., Mademoiselle Miss (Liskeard: Diggory Press, 2006 [1916]): 31.

13 Anon., Mademoiselle Miss: preface.

14 Anon., Mademoiselle Miss: preface.

15 Anon., Mademoiselle Miss: 14.

16 Anon., Mademoiselle Miss: 28-30.

17 Florence Farmborough: oral history interview conducted by Margaret A. Brooks, 1975, 17 reels, Imperial War Museum, London, Reel 1. On 'self-composure', see: Penny Summerfield, Reconstructing Women's Wartime Lives (Manchester: Manchester University Press, 1998): 16-23.

18 Farmborough gave another interview - to Peter Liddle - Florence Farmborough: oral history interview conducted by Peter Liddle at Abbeyfield House, The Mount, Heswall, 1975, Liddle Collection, Brotherton Library, University of Leeds. Farmborough's original diaries are held at the Imperial War Museum, London: Florence Farmborough, diaries, private papers, 1381. Her memoir, Nurse at the Russian Front, was published in 1974; and her Russian Album, a collection of her own photographs, in 1979. Florence Farmborough, Nurse at the Russian Front: A Diary, 1914-18 (London: Book Club Associates, 1974), later republished in a new edition: Florence Farmborough, With the Armies of the Tsar: A Nurse at the Russian Front in War and Revolution, 1914-1918 (New York: Cooper Square Press, 2000); Florence Farmborough, Russian Album 1908-1918, ed. John Jolliffe (Wilton: Michael Russell, 1979). See also: Peter Liddle, Captured Memories 1900-1918: Across the Threshold of War (Barnsley: Pen and Sword, 2010), Chapter 16, 'Florence Farmborough F.R.G.S.': 231-44.

19 Farmborough, Russian Album: 7.

20 Oral history interview conducted by Margaret A. Brooks: Reel 1.

21 Oral history interview: conducted by Margaret A. Brooks: Reel 1.

22 Farmborough, Russian Album: 9; Oral history interview conducted by Margaret A. Brooks: reel 1.

23 Oral history interview conducted by Margaret A. Brooks: reel 2.

24 Farmborough, Russian Album: 27.

25 See Chapter 6. 
26 Farmborough, Russian Album: 27-8. On the work of British nurses in flying columns, see: Christine Hallett, 'Russian Romances: Emotionalism and Spirituality in the Writings of "Eastern Front" Nurses', 1914-1918, Nursing History Review, 17 (2009): 101-28.

27 Farmborough, Russian Album: 9.

28 Farmborough, Nurse at the Russian Front: 396.

29 On the tradition of British travel writing in Russia, see: Anthony Cross, 'From the Assassination of Paul I to Tilsit: The British in Russia and Their Travel Writings (1801-1807), Journal of European Studies, 42.1 (2012): 5-21. See also: Katya Hokanson, 'Russian Women Travellers in Central Asia and India', Russian Review, 70.1 (2011): 1-19.

30 Farmborough, Nurse at the Russian Front: 128.

31 Farmborough, Nurse at the Russian Front: 130-1.

32 Farmborough, Nurse at the Russian Front: 131.

33 Farmborough, Nurse at the Russian Front: 230.

34 Farmborough, Nurse at the Russian Front: 229-30.

35 Farmborough, Nurse at the Russian Front: 230.

36 Susan Grant, 'Nursing in Russia and the Soviet Union, 1914-41: An Overview of the Development of a Soviet Nursing System, Bulletin of the UK Association for the History of Nursing, 2 (2012): 21-33; Laurie Stoff, 'The "Myth of the War Experience" and Russian Wartime Nursing in World War I', Aspasia: The International Yearbook of Central, Eastern, and Southeastern European Women's and Gender History, 6 (2012): 96-116; Hallett, Veiled Warriors: Chapter 3.

37 Mary Britnieva, One Woman's Story (London: Arthur Baker, 1934).

38 Britnieva, One Woman's Story: 209.

39 Britnieva, One Woman's Story: 258.

40 Britnieva, One Woman's Story: 9-13.

41 At one point, she refers to him briefly as 'Sasha': Britnieva, One Woman's Story: 89.

42 Britnieva, One Woman's Story: 10.

43 Britnieva, One Woman's Story: 15.

44 Both Violetta Thurstan and Florence Farmborough write of long treks through forests and farmland: Violetta Thurstan, Field Hospital and Flying Column: Being the Journal of an English Nursing Sister in Belgium and Russia (London: G. P. Putnam's Sons, 1915); Farmborough, Nurse at the Russian Front. See also: Hallett, 'Russian Romances'.

45 Britnieva, One Woman's Story: 27.

46 Britnieva, One Woman's Story: 31.

47 Britnieva, One Woman's Story: 51.

48 Britnieva, One Woman's Story: 64.

49 Britnieva, One Woman's Story: 67. 


\section{Volunteer girls}

50 On the Russian Revolution, see: Orlando Figes, A People's Tragedy: The Russian Revolution, 1891-1924 (London: Pimlico, 1997 [1996]); Sheila Fitzpatrick, The Russian Revolution, 3rd edn (Oxford: Oxford University Press, 2008). On the New Economic Policy of 1921, see: Chris Ward, Russia's Cotton Workers and the New Economic Policy: Shop Floor Culture and State Policy, 1921-1929 (Cambridge: Cambridge University Press, 2002).

51 Fitzpatrick, The Russian Revolution: 1. See also: Figes, A People's Tragedy.

52 Britnieva, One Woman's Story: 69.

53 Fitzpatrick, The Russian Revolution: 22.

54 'They had all committed the same crime, the crime of being educated and cultured': Britnieva, One Woman's Story: 237.

55 Britnieva, One Woman's Story: 279.

56 Claire Tylee, The Great War and Women's Consciousness: Images of Militarism and Womanhood in Women's Writings, 1914-64 (Houndmills and London: Macmillan, 1990). 